\title{
BEST PRACTISE MENGEMBANGKAN SIKAP ILMIAH DAN KETERAMPILAN PROSES PESERTA DIDIK MELALUI METODE AJAR PROBLEM BASED LEARNING
}

\author{
EVY ALDIYAH \\ Guru IPA SMP Negeri 202 Jakarta \\ E-mail : evyaldy@gmail.com
}

\begin{abstract}
ABSTRAK
Kegiatan penyiapan peserta didik sebagai generasi yang berkualitas dapat dibentuk berlandaskan kompetensi intelektual, keterampilan proses, sikap ilmiah, keterampilan berkomunikasi dan kemampuan menulis karya ilmiah. Hal itu dapat diimplementasikan dengan keikutsertaan dalam ajang lomba penelitian. Sementara peran guru sebagai pembimbing dan pengarah sangat mendukung dalam menggali potensi yang dimiliki peserta didik. Tujuan dibuatnya best practice ini adalah mendeskripsikan pengalaman penulis membimbing peserta didik mengikuti lomba penelitian IPA guna mengembangkan sikap ilmiah dan keterampilan proses peserta didik. Pelaksanaan pembimbingan peserta didik menggunakan pendekatan belajar metode Problem Based Learning. Pembimbingan dan mempersiapkan peserta didik mengikuti lomba penelitian ini layak dijadikan best practice ditinjau dari peningkatan keterampilan proses dan sikap ilmiah peserta didik. Penyusunan pelaksanaan kegiatan yang sistematis dan cermat menggunakan model belajar PBL tidak sekedar memenuhi target keikutsertaan lomba, tetapi juga sudah mengintegrasikan PPK, literasi dan kecakapan hidup abad 21 pada peserta didik, selain itu juga meningkatkan kemampuan peserta didik dalam melakukan transfer pengetahuan, berpikir kritis dan pemecahan masalah. Sebagai seorang guru tidak hanya memiliki kompetensi dalam kegiatan belajar mengajar di kelas tetapi harus berani melakukan inovasi diluar konteks guru mengajar di kelas, sebagai contoh guru menjadi pembimbing lomba penelitian peserta didik. Menjadi suatu kebanggaan tersendiri bila peserta didik yang menjadi bimbingan mencapai prestasi sesuai yang diharapkan bahkan melebihi ekspektasi, dimana kebanggaaan itu tidak hanya dirasakan oleh peserta didik dan guru pembimbingnya saja tetapi semua warga sekolah ikut merasakan kebanggaan itu.
\end{abstract}

Kata kunci : Sikap ilmiah, Keterampilan proses, penelitian IPA, metode belajar PBL

\section{PENDAHULUAN}

Menurut Kurniawan (2012) dalam Rerung, Sinon, \& Widyaningsih (2017) pendidikan merupakan kegiatan mengoptimalkan perkembangan potensi, kecakapan, serta karakteristik pribadi peserta didik dimana kegiatan pendidikan diarahkan pada pencapaian tujuan pendidikan. Pengembangan potensi dan keterampilan peserta didik sebagaimana yang diarahkan tujuan pendidikan di Indonesia dapat digunakan sebagai bekal menjalani hidup di masyarakat, bangsa dan negara. Salah satu keterampilan yang dimaksud adalah keterampilan proses sains (Elvanisi, Hidayat, \& Fadillah, 2018). Menurut Prasati (2017) dalam Elvansi, Ade et al (2018) bahwa tujuan dari keterampilan proses sains adalah mengembangkan keaktifan peserta didik dalam memahami apa yang dilakukannya seperti mengamati (observe), mengelompokkan (classify) menafsirkan (interpret), meramalkan (predict), membuat hipotesa (hypothesis), merencanakan percobaan penelitian (planning research experiment) dan mengkomunikasikan hasil (communicate the results).

Peserta didik diharapkan terlibat secara aktif dalam membangun pemahaman yang dimiliki dengan seluruh kemampuan mereka hingga menemukan jawaban atas keingintahuan mereka, sehingga pengembangan potensi dan keterampilan menjadi lebih bermakna, sebagaimana yang dikemukakan oleh Corley (2010) dalam Fatimah, Susilo, \& Diantoro (2016). Selanjutnya Ozgelen (2012) dalam Fatimah, Fitri et al (2016) mengemukakan bahwa untuk 
mengkonstruksi pengetahuan, serta pemecahan masalah dan membuat kesimpulan dibutuhkan keterampilan proses sebagai kompetensi dasar penyelidikan ilmiah.

Dalam buku Panduan Pelaksanaan Teknis OPSI 2018 yang diterbitkan oleh Kemendikbud RI dijelaskan bahwa Indonesia memasuki masa pembangunan jangka menengah tahap ketiga dimana tantangan terbesarnya adalah sumber daya manusia Indonesia yang berkualitas dan memiliki daya saing tinggi di dunia pendidikan, untuk itu peserta didik harus terlibat dalam berbagai kegiatan ekstrakurikuler dan ko-kurikuler dengan sifat terpadu dan komprehensif sebagai pola pembinaan kesiswaan. Pola pembinaan yang dilakukan di sekolah adalah sebagai kegiatan penyiapan generasi yang berkualitas yang dibentuk di atas landasan kompetensi intelektual, keterampilan dan sikap, berpikir logis dan analitis, bekerja sama dalam kelompok, mandiri, kepercayaan diri yang tinggi, serta keterampilan berkomunikasi dan kemampuan menulis karya ilmiah dengan didasari sikap-sikap ilmiah.

Menurut Dimyati dan Mudjiono (2006) dalam Juhji (2016) bahwa peserta didik adalah penentu terjadi atau tidak terjadinya proses belajar sehingga proses belajar menjadi suatu hasil yang kompleks, Sedangkan guru berperan sebagai pembimbing dan pengarah. Jadi menurut Juhji (2016), proses itu sendiri dapat bergerak datangnya oleh peserta. Sehingga guru perlu melakukan pendekatan yang membimbing dan mengarahkan peserta didik untuk berperan secara aktif dalam menggali potensi yang ada pada dirinya, pada akhirnya peserta didik mampu mengembangkan keterampilan proses sains seperti mengobservasi, mengklasifikasi, memprediksi, mengukur, menyimpulkan, dan mengkomunikasikan.

Salah satu metode pembelajaran yang mendukung pengembangan sikap ilmiah peserta didik adalah Problem Based Learning. Menurut Duch (1995) dalam Ningsih, S.(2014) metode PBL bercirikan adanya permasalahan nyata sebagai konteks untuk para peserta didik belajar berpikir kritis dan keterampilan memecahkan masalah, dan memperoleh pengetahuan, dengan tahapan atau fase sebagai berikut :

Tabel 1. Fase atau Tahapan Pembelajaran Problem Based Learning

\begin{tabular}{|c|c|}
\hline $\begin{array}{l}\text { Fase atau Tahapan } \\
\text { Metode PBL }\end{array}$ & Perilaku Guru \\
\hline $\begin{array}{l}\text { Fase 1: Orientasi peserta didik } \\
\text { terhadap masalah }\end{array}$ & $\begin{array}{l}\text { Menginformasikan tujuan-tujuan pembelajaran, } \\
\text { mendiskripsikan kebutuhan-kebutuhan logistik penting, } \\
\text { dan memotivasi agar terlibat dalam kegiatan pemecahan } \\
\text { masalah yang mereka pilih }\end{array}$ \\
\hline $\begin{array}{l}\text { Fase } 2 \text { Mengorganisasikan } \\
\text { peserta didik }\end{array}$ & $\begin{array}{l}\text { Membantu peserta didik untuk mendefinisikan, } \\
\text { mengorganisasikan tugas yang terkait dengan } \\
\text { permasalahan yang diorientasi dan mencoba membuat } \\
\text { hipotesis atas masalah yang ditemukan }\end{array}$ \\
\hline $\begin{array}{l}\text { Fase 3: Membimbing } \\
\text { penyelididkan mandiri dan } \\
\text { kelompok }\end{array}$ & $\begin{array}{l}\text { Mendorong siswa mengumpulkan informasi yang } \\
\text { sesuai sebanyak-banyaknya, melaksanakan eksperimen, } \\
\text { menciptakan dan membagikan ide mereka sendiri untuk } \\
\text { mendapatkan penjelasan serta solusi }\end{array}$ \\
\hline $\begin{array}{l}\text { Fase 4: Mengembangkan dan } \\
\text { menyajikan hasil karya serta } \\
\text { memamerkannya }\end{array}$ & $\begin{array}{l}\text { Membantu peserta didik dalam menganalisis data yang } \\
\text { telah dikumpulkan, menyesuaikan data dengan masalah, } \\
\text { mengelompokkan berdasarkan kategorinya, } \\
\text { merencanakan dan menyiapkan hasil karya sesuai } \\
\text { seperti laporan, membantu peserta didik } \\
\text { menyampaikannya ke orang lain. Karya dapat berupa } \\
\text { laporan, video, rekaman, atau model }\end{array}$ \\
\hline $\begin{array}{l}\text { Fase } 5: \text { Menganalisis dan } \\
\text { mengevalusi proses pemecahan } \\
\text { masalah }\end{array}$ & $\begin{array}{l}\text { Membantu peserta didik melakukan refleksi terhadap } \\
\text { investigasinya dan proses yang telah mereka lakukan. }\end{array}$ \\
\hline
\end{tabular}


Berdasarkan hal yang telah dipaparkan di atas, peserta didik SMP Negeri 202 Jakarta diharapkan dapat mengembangkan dan mengeksplor sikap ilmiah dalam berbagai aspek kehidupannya. Menurut Enderle, dkk (2012) dalam Ulva, V., Ibrohim, \& Sutopo (2017), sikap ilmiah mendorong peserta didik untuk melakukan penyelidikan, mengeksplorasi dan menyelidiki lingkungan. Dalam hal ini diharapkan peserta didik SMP Negeri 202 Jakarta mampu bersaing dengan yang lainnya dalam keikutsertaan lomba penelitian IPA.

Melihat daya dukung lokasi pelaksanaan pembelajaran, peserta didik SMP Negeri 202 Jakarta siap bersaing sebagai generasi milenial yang intelektual dan terampil dengan mengintegrasikan PPK, literasi dan kecakapan hidup abad 21. Hal itu diimplementasikan dengan keikutsertaan dalam lomba penelitian IPA LPSN/OPSI 2018 Tingkat Wilayah Jakarta Timur 1 dengan menyandang Juara 1. Dalam pembimbingan peserta didik dilakukan pendekatan belajar menggunakan metode Problem Based Learning, dimana metode PBL ini sangat memungkinkan untuk diterapkan dengan berdasarkan pertimbangan karakteristik siswa yang terbilang cukup kooperatif, namun masih perlu bimbingan dan didampingi agar mau mengoptimalkan potensinya. Selain itu, karakteristik materi pelajaran IPA biologi sangat memungkinkan untuk dijadikan bahan penelitian dengan rangkaian kegiatan aktif, mengamati, mencoba, mengeksplorasi, menalar, menyimpulkan, dan mengkomunikasikan. Yang tidak kalah penting adalah daya dukung sekolah, di mana ketersediaan lahan pengamatan, laboratotium IPA dengan alat-alatnya dan literatur yang tersedia di perpustakaan.

Tujuan dibuatnya best practice ini adalah mendeskripsikan pengalaman penulis membimbing peserta didik mengikuti lomba penelitian guna mengembangkan sikap ilmiah dan keterampilan proses peserta didik. Manfaat setelah berbagi pengalaman melalui best practice ini : 1) Bagi peserta didik, dapat menjadi motivasi untuk meningkatkan belajar IPA, 2) Bagi guru dan peneliti, best practice ini diharapkan dapat memberikan kontribusi keilmuan di masa mendatang serta sebagai bahan kajian untuk meningkatkan profesionalisme guru sebagai peneliti.

\section{METODE PELAKSANAAN KEGIATAN}

Penelitian ini merupakan penelitian deskriptif yang menggambarkan bagaimana suatu teknik pembimbingan peserta didik dengan metode yang diterapkan dan bagaimana hasil yang diinginkan dapat dicapai. Sasarannya adalah peserta didik SMP Negeri 202 Jakarta yang dilibatkan dalam team berjumlah 3 orang berasal dari level kelas tinggi. Kegiatan penelitian memanfaatkan lingkungan dan benda-benda termasuk makhluk hidup di lingkungan sekitar terutama di kebun sekolah. Materi penelitian berupa penelitian biologi murni tentang pemanfaatan daun pepaya sebagai pestisida alami, dan mengambil judul Efektivitas Ekstrak Daun Pepaya Terhadap Aktivitas Kutu Daun.

Pelaksanaan kegiatan berupa pembimbingan dan pelatihan penelitian terhadap team peserta didik. Dalam pembimbingan pelatihan penelitian digunakan metode belajar PBL. Metode ini memberikan kesempatan peserta didik untuk beraktifitas, berpikir aktif dan kritis untuk menemukan sendiri jawaban dari permasalahan yang ada. Sehingga muara dari pembelajaran ini adalah penguasaan peserta didik terhadap konten materi tertentu (fakta, konsep, teori, prinsip, hokum, dan lain-lain) serta terbentuknya sikap berani, jujur, aktif, bertanggungjawab, mau bekerjasama, dan sikap-sikap positif lainnya

Adapun tahap pelaksanaan penelitian yang dilakukan peserta didik. terdiri dari 5 tahap pelaksanaan yaitu 1) Tahap Awal, pra penelitian, 2) Tahap Pembimbingan Penelitian, 3) Tahap Pembimbingan Pembuatan Makalah, 4) Tahap Akhir, evaluasi kegiatan dan latihan presentasi, 5) Tahap Lomba Presentasi Penelitian. Dalam setiap tahapan kegiatan team peserta didik dibimbing oleh guru pembimbing dan menerima masukan dari guru pembimbing. 
Tahapan pelaksanaan tersebut dikaitkan dengan metode belajar PBL. Melihat daya dukung lokasi pelaksanaan pembelajaran, yakni di SMP Negeri 202 Jakarta metode belajar PBL ini sangat memungkinkan untuk diterapkan dengan berdasarkan pertimbangan karakteristik siswa yang terbilang cukup kooperatif, namun masih perlu untuk didampingi agar mau mengoptimalkan potensinya. Selain itu, karakteristik materi pelajaran IPA bidang ilmu biologi sangat memungkinkan untuk dijadikan bahan penelitian dengan rangkaian kegiatan belajar aktif, seperti mengamati, mencoba, mengekspolarasi, menalar, menyimpulkan, dan mengkomunikasikan. Yang tidak kalah penting adalah daya dukung sekolah, di mana ketersediaan lahan pengamatan, laboratotium IPA dengan alat-alatnya dan literatur yang tersedia di perpustakaan serta jaringan internet sekolah.

Pelaksanaan kegiatan dilakukan di kebun sekolah dan laboratorium IPA SMP Negeri 202 Jakarta. Waktu pelaksanaan kegiatan mulai tanggal 19 Agustus 2018 hingga 28 Agustus 2018. Lomba Presentasi penelitian dilaksanakan pada tanggal 6 September di Kantor Walikota Kota Administratif Wilayah 1 Jakarta Timur. Tim juri berjumlah 5 orang berasal dari jajaran Sudin Dikdas Kota Administratif Wilayah 1 Jakarta Timur dan dari jajaran praktisi pendidikan (dosen) Universitas Negeri Jakarta.

\section{HASIL DAN PEMBAHASAN}

Berikut adalah langkah pelaksanaan kegiatan penelitian dimana dalam setiap tahapan kegiatan team peserta didik dibimbing oleh guru pembimbing dan menerima masukan dari guru pembimbing, dimana penulis adalah sebagai guru pembimbingnya.

Tabel 2. Pelaksanaan Kegiatan Penelitian

\begin{tabular}{|c|c|c|}
\hline No & Pelaksanaan Kegiatan & Waktu \\
\hline & Tahap Awal & \\
\hline 1 & $\begin{array}{l}\text { Menentukan anggota team peserta didik : peserta didik dipilih sesuai } \\
\text { dengan karakter untuk kegiatan dilanjutkan dengan menentukan judul } \\
\text { dan materi penelitian dilanjutkan dengan survey lapangan di kebun } \\
\text { sekolah. }\end{array}$ & 19/8/2018 \\
\hline 2 & $\begin{array}{l}\text { Diskusi bersama antara peserta didik dengan guru pembimbing : team } \\
\text { peserta didik menerima saran dan masukan dari guru pembimbing } \\
\text { dilanjutkan menyiapkan instrument kegiatan dan lembar kerja. }\end{array}$ & $20 / 8 / 2018$ \\
\hline & Pembimbingan Penelitian & \\
\hline 3 & $\begin{array}{l}\text { Persiapan pengamatan : mempersiapkan alat dan bahan yang diperlukan } \\
\text { sekaligus pengamatan lapangan, mencatat data dan semua informasi } \\
\text { terkait materi penelitian termasuk dokumentasi berupa poto. }\end{array}$ & $21 / 8 / 2018$ \\
\hline 4 & $\begin{array}{l}\text { Kegiatan di kebun sekolah : mengambil bahan yang dibutuhkan (daun } \\
\text { pepaya) dilanjutkan dengan penimbangan bahan, kegiatan diulangi bila } \\
\text { belum mencapai hasil yang terbaik, semua langkah kerja dilakukan } \\
\text { sesuai dengan langkah-langkah pada lembar kerja. }\end{array}$ & $21 / 8 / 2018$ \\
\hline 5 & $\begin{array}{l}\text { Kegiatan di laboratorium : membuat ekstrak berbahan daun pepaya, } \\
\text { membuat beberapa konsentrasi larutan ekstrak yang berbeda, kegiatan } \\
\text { diulangi bila belum mencapai hasil yang terbaik, semua langkah kerja } \\
\text { dilakukan sesuai dengan langkah-langkah pada lembar kerja. }\end{array}$ & $22 / 8 / 2018$ \\
\hline 6 & $\begin{array}{l}\text { Pengamatan percobaan : menyiapkan sampel kutu daun pada tanaman } \\
\text { cabe rawit yang diambil dari kebun sekolah, melakukan perlakuan } \\
\text { terhadap sampel kutu daun, melakukan pengamatan percobaan, } \\
\text { mencatat hasil pengamatan, menganalisa hasil percobaan dan membuat } \\
\text { kesimpulan hasil percobaan, semua langkah kerja dilakukan sesuai } \\
\text { dengan langkah-langkah pada lembar kerja, mengulangi kegiatan bila } \\
\text { salah selalu dilakukan hingga mencapai hasil yang maksimal. }\end{array}$ & $22 / 8 / 2018$ \\
\hline
\end{tabular}


III. Tahap Pembimbingan Pembuatan Makalah

7 Pembuatan makalah penelitian : melakukan pencarian literatur pendukung baik dari majalah, koran, atau internet dengan mengikuti saran dan masukan dari guru pembimbing, menyelesaikan pembuatan makalah penelitian secara sederhana sesuai waktu yang ditetapkan, mengulangi kegiatan bila salah selalu dilakukan hingga mencapai hasil yang maksimal.

\section{Tahap Akhir}

8 Evaluasi hasil : menganalisa hasil penelitian sejak awal hingga akhir, 26/8/2018 melakukan perbaikan yang dianggap perlu untuk mencapai hasil terbaik.

9 Pelatihan mengkomunikasikan hasil penelitian : melakukan latihan 26/8/2018 presentasi penelitian dibimbing oleh guru pembimbing dan beberapa guru yang berperan sebagai juri, pelatihan diilakukan berulang-ulang 28/8/2018 hingga mencapai hasil yang maksimal.

\section{Tahap Lomba Presentasi}

10 Presentasi hasil penelitian : melakukan presentasi di hadapan para juri Lomba Penelitian IPA Siswa Nasional (LPSN), juri terdiri dari jajaran Suku Dinas Pendidikan Wilayah 1 Jakarta Timur dan jajaran Praktisi Pendidikan Universitas Negeri Jakarta (dosen).

Team peserta didik SMP Negeri 202 terpilih sebagai Juara 1 Tingkat Wilayah Jakarta Timur.

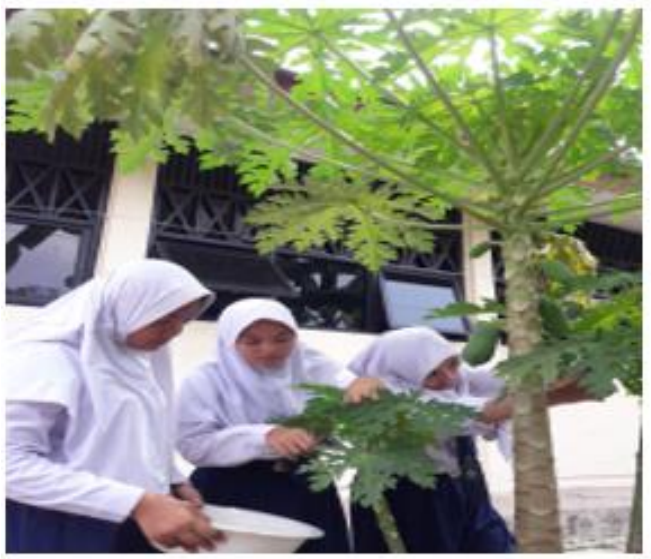

Gambar 1. Peserta didik mengumpulkan daun pepaya di kebun sekolah.

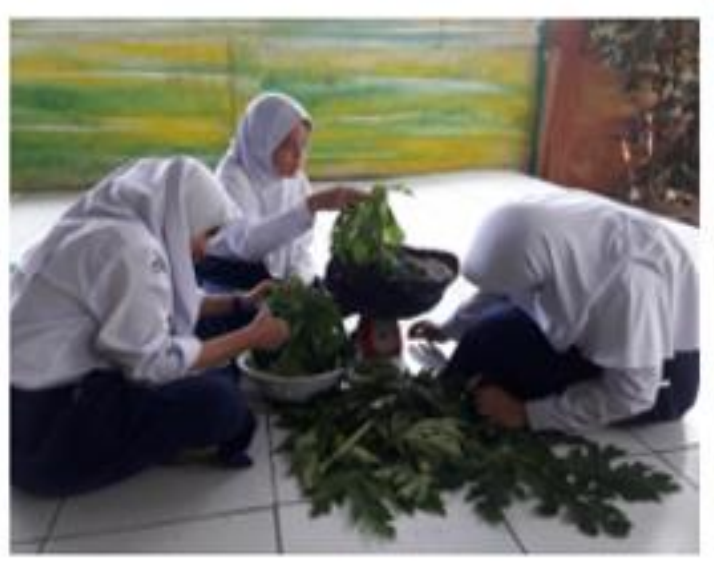

Gambar 2. Peserta didik menimbang daun pepaya untuk pembuatan ekstrak sebagai bahan dasar pestisida, di kebun sekolah.

Pada penelitian awal team peserta didik mengumpulkan bahan yang dibutuhkan yakni daun pepaya yang diambil dari kebun sekolah, seperti tampak pada gambar 1. Dilanjutkan dengan penimbangan daun pepaya untuk kebutuhan, seperti tampak pada gambar 2 . Pengukuran dilakukan dengan akurat dan diulangi bila belum mencapai hasil yang terbaik. Kegiatan ini dilakukan di kebun sekolah. 


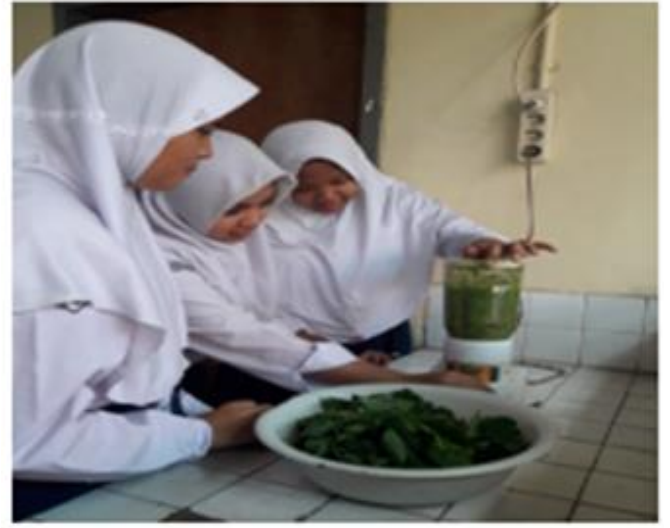

Gambar 3. Peserta didik menghaluskan daun pepaya menjadi ekstrak bahan pestisida di lab IPA

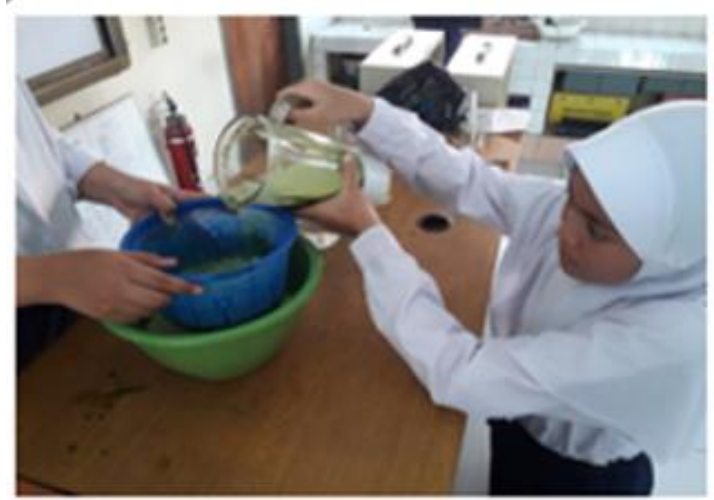

Gambar 4. Peserta didik membuat campuran ekstrak daun pepaya dengan bahan lain menjadi larutan pestisida.

Pada gambar 3 dan gambar 4, team peserta didik menghaluskan helai daun pepaya mengunakan blender untuk diambil ekstraknya lalu mencampurnya dengan bahan-bahan tambahan seperti air, deterjen dan minyak tanah sehingga menjadi larutan pestisida yang diinapkan selama satu malam. Kegiatan ini dilakukan di laboratorium IPA.

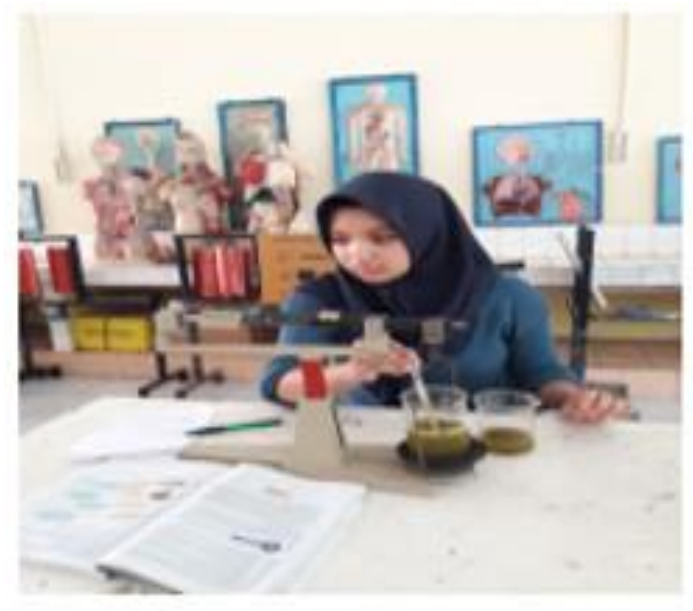

Gambar 5. Peserta didik menyiapkan larutan pestisida dengan beberapa perbedaan konsentrasi larutan di lab IPA.

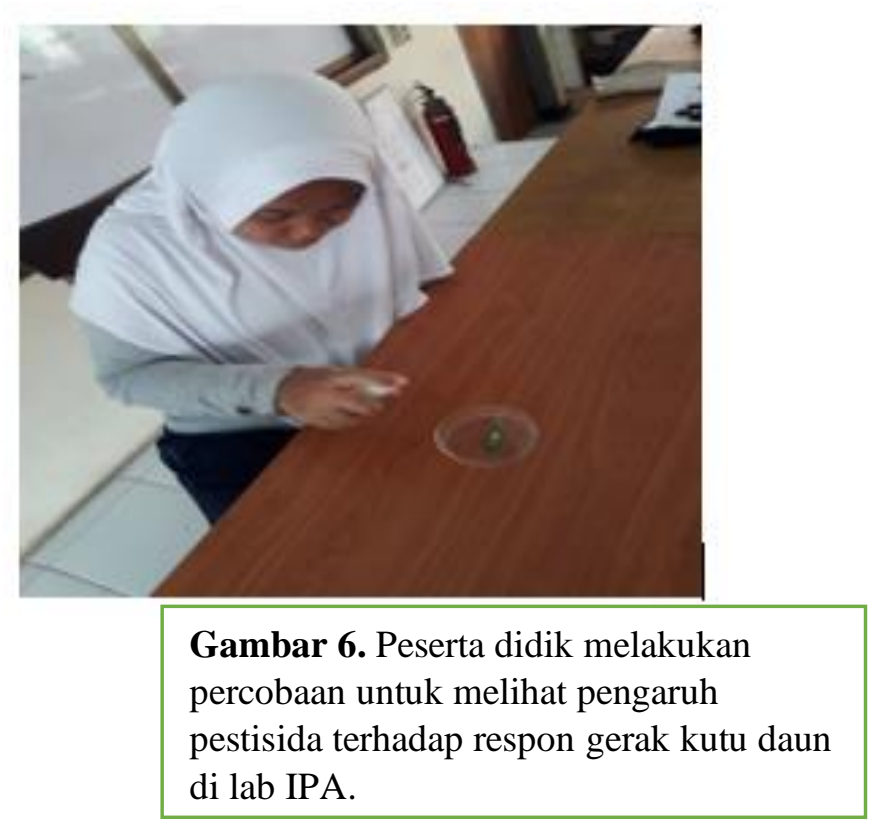

Esok harinya di laboratorium IPA, team peserta didik menyiapkan larutan konsentrasi pestisida, pada gambar 5 tampak peserta didik sedang melakukan penimbangan bahan ekstrak pestisida dengan tiga konsentrasi (konsentrasi rendah, konsentrasi menengah dan kosentrasi tinggi). Untuk selanjutnya dilakukan percobaan terhadap respon gerak kutu daun terhadap cairan pestisida alami seperti tampak pada gambar 6, lalu dilakukan pengamatan menggunakan metode Analisis Deskriptif. Dari hasil penelitian tersebut team peserta didik membuat makalah penelitian sederhana dibimbing oleh guru pembimbing. Materi inilah yang dipersiapkan untuk mengikuti Lomba Presentasi penelitian. 


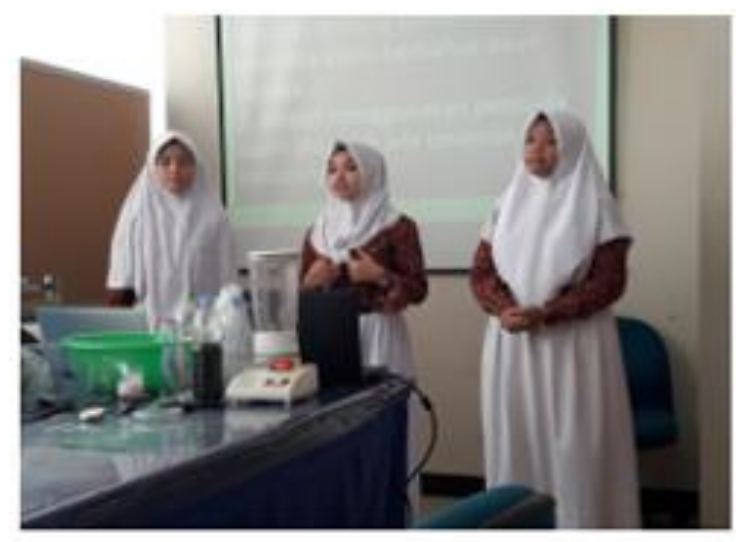

Gambar 7. Peserta didik tengah menjalani lomba presentasi penelitian di hadapan para juri di Kantor Walikota Kota Administratif Jakarta Timur Wilavah 1.

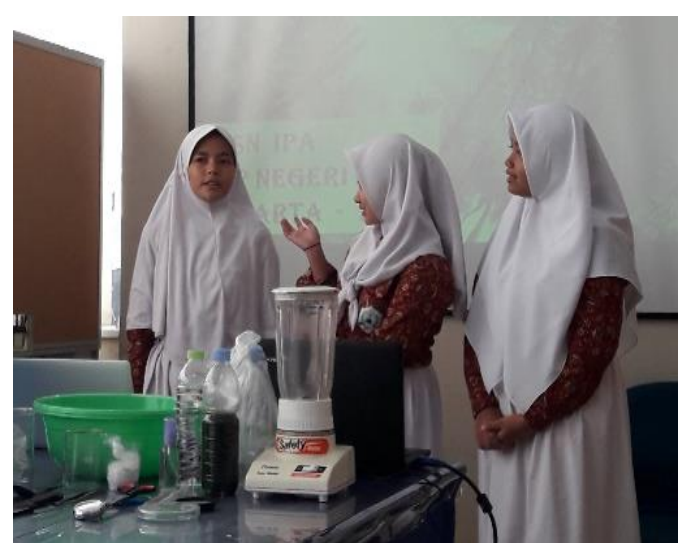

Gambar 8. Peserta didik dengan sigap dan lancar menjawab pertanyaan para juri pada lomba presentasi penelitian.

Pada gambar 7 dan gambar 8 team peserta didik tampak tengah menjalani lomba presentasi penelitian di hadapan para juri. Dengan bangga mengemukakan penelitian yang telah mereka lakukan serta dengan sigap dan lancar menjawab pertanyaan para juri.

Setelah menjalani tes di hadapan para juri pada Lomba Presentasi penelitian yang dilaksanakan pada tanggal 6 September di Kantor Walikota Kota Administratif Jakarta Timur Wilayah 1, team peserta didik SMP Negeri 202 terpilih sebagai Juara 1 Lomba Penelitian IPA Siswa (LPSN) se Wilayah 1 Jakarta Timur. Ini merupakan suatu pencapaian yang luar biasa. Keberhasilan ini didorong oleh beberapa faktor yakni: (1) Adanya kerjasama yang baik antar anggota team dan usaha keras yang dilakukan, (2) Pembimbingan yang dilakukan secara maksimal oleh guru pembimbing sehingga berkembangnya keterampilan proses team peserta didik, (3) Daya dukung sekolah yang mendukung pelaksanaan kegiatan.

Dalam pembimbingan kegiatan ini terdapat beberapa masalah seperti ketidakakuratan dalam melakukan pengamatan awal, pada percobaan, juga dalam penghitungan konsentrasi bahan, tetapi peserta didik selalu diberikan pemahaman serta dilakukan berkali-kali pengulangan langkah kegiatan bila salah hingga hasilnya sesuai yang diharapkan. Demikian pula dalam pembuatan makalah penelitian, peserta didik banyak diberikan pemahaman dan bimbingan yang mendalam tentang materi dan sistematika penulisan

Ada beberapa hal yang penulis amati tampak pada peserta didik setelah dilakukan pembimbingan menggunakan pendekatan metode ajar PBL ini yaitu tumbuh karakter berusaha untuk mencari penyelesaian masalah baik di dalam kelas maupun masalah dalam kehidupan sehari-hari, selanjutnya peserta didik menjadi terbiasa berdiskusi bersama teman dan gurunya. Hal ini sesuai dengan yang dikemukakan oleh Warsono \& Hariyanto (2012), bahwa pembelajaran metode PBL memiliki keunggulan dalam : 1) menciptakan karakter peserta didik yang terbiasa menghadapi masalah dan menyelesaikannya ,2) menumbuhkan sikap solidaritas sosial antar teman, 3) menciptakan hubungan yang akrab antara peserta didik dengan guru, dan 4) membiasakan peserta didik melakukan eksperimen untuk menjawab permasalahan yang ditemuinya. Selain itu peserta didik juga menjadi terbiasa untuk bekerja secara sistematis dalam menyelesaikan suatu masalah. Hal ini juga sesuai seperti yang dikemukakan oleh Shofiyah, Noly \& Wulandari, E, Fitria (2018), bahwa di dalam PBL peserta didik harus menyusun kegiatan secara sistematis, dimana hal itu sangat dibutuhkan dalam penyelesaian masalah dan menghadapi tantangan dalam kehidupan sehari-hari.

Hasil dari best practice ini diharapkan memberikan dampak positif baik secara langsung maupun secara tak langsung terhadap sikap dan karakter peserta didik , terhadap kegiatan guru 
dan juga terhadap pelaksanaan kegiatan sekolah, yaitu : 1) Ada peningkatan motivasi belajar IPA bagi peserta didik, 2) Menambah pengalaman baru bagi peserta didik tentang pengalaman belajar, 3) Guru mengembangkan ilmunya dan termotivasi menjadi guru hebat berkompetensi, 4) Pihak sekolah mengagendakan kegiatan rutin pembimbingan siswa mempersiapkan generasi milenial yang intelektual dan terampil dengan mengintegrasikan PPK, literasi dan kecakapan hidup abad 21 yang siap bersaing.

Salah satu cara mengembangkan keterampilan proses peserta didik adalah melalui penerapan metode belajar PBL melalui penyelidikan. Pentingnya pengembangan keterampilan proses sebagai dasar pengembangan sikap ilmiah, diharapkan dapat membentuk pribadi peserta didik yang kreatif, kritis, inovatif dan kompetitif menuju persaingan global, sebagaimana dikemukakan oleh Turiman dkk (2012) dalam Fatimah, Fitri et al (2016). Menurut Sanjaya (2008) dalam Rerung, Sinon, \& Widyaningsih (2017), komponen penting dalam sebuah kurikulum selain merumuskan tujuan untuk memperjelas pendidikan ada hal yang menjadi lebih penting lagi yaitu memberikan pemahaman tentang pengalaman belajar yang harus dimiliki peserta didik. Dan kegiatan pembimbingan peserta didik sebagaimana pengalaman penulis dalam best practice ini dapat dikatakan sebagai salah satu cara memberikan pemahaman kepada peserta didik tentang pengalaman belajar.

\section{KESIMPULAN}

Kesimpulan yang dapat diambil dari penulisan best practice ini adalah : 1) Pembimbingan dan mempersiapkan peserta didik mengikuti lomba penelitian ini layak dijadikan best practice ditinjau dari peningkatan keterampilan proses dan sikap ilmiah peserta didik. 2) Dengan penyusunan pelaksanaan kegiatan yang sistematis dan cermat menggunakan model belajar Problem Based Learning tidak sekedar memenuhi target keikutsertaan lomba, tetapi juga sudah mengintegrasikan PPK, literasi dan kecakapan hidup abad 21 pada peserta didik, selain itu juga meningkatkan kemampuan peserta didik dalam melakukan transfer pengetahuan, berpikir kritis dan pemecahan masalah. Dan 3) Sebagai seorang guru tidak hanya memiliki kompetensi dalam kegiatan belajar mengajar di kelas tetapi harus berani melakukan inovasi diluar konteks guru mengajar di kelas, sebagai contoh guru menjadi pembimbing lomba penelitian peserta didik. Menjadi suatu kebanggaan tersendiri bila peserta didik yang menjadi bimbingan mencapai prestasi sesuai yang diharapkan bahkan melebihi ekspektasi. Dimana kebanggaaan itu tidak hanya dirasakan oleh peserta didik dan guru pembimbingnya saja, tetapi semua warga sekolah ikut merasakan kebanggaan itu.

\section{DAFTAR PUSTAKA}

Elvanisi, Ade., Hidayat, Saleh., \& Fadillah, N. Etty. (2018) Analisis keterampilan proses sains siswa sekolah menengah atas. Jurnal Inovasi Pendidikan IPA, 4(2). http://jouna.uny.ac.id/index.php/jipi, diakses 1 Oktober 2018. from DOI : https://doi.org/10.21831/jipi.v4i2.21426

Fatimah, Fitri., Susilo, Herawati, \& Diantoro, Markus (2016). Keterampilan Proses Sains Siswa Kelas VII Dengan Pembelajaran Model Levels of Inquiry. Jurnal Pendidikan: Teori, Penelitian, dan Pengembangan Volume: 1 Nomor: 9 Bulan September Tahun 2016, from DOI : http://dx.doi.org/10.17977/jp.v1i9.6829

Juhji (2016). Peningkatan Keterampilan Proses Sains Siswa Melalui Pendekatan Inkuiri

Terbimbing. Jurnal Penelitian dan Pembelajaran IPA e-ISSN 2477-2038, JPPI, Vol. 2, No. 1, Juni 2016, Hal. 58-70, DOI: http://dx.doi.org/10.30870/jppi.v2i1.419

Kemendikbud (2018). Panduan Pelaksanaan Olimpiade Penelitian Siswa Indonesia (OPSI) 2018. Direktorat Pembinaan Sekolah Menengah Atas - Dirjen Pendidikan 
Dasar dan Menengah Kementerian Pendidikan dan Kebudayaan Indonesia. http://repositori.kemendikbud.go.id

Lestari, A.P.A.N. Siti., Jayadinata, K, Asep., \& Aeni, n. Ani (2017). Meningkatkan Keterampilan Proses Sains Siswa Pada Materi Sifat-Sifat Cahaya Melalui Pembelajaran Inkuiri.. Jurnal Pena Ilmiah: Vol 2, No 1 (2017) 621 from DOI: https://doi.org/10.17509/jpi.v2i1.10051

Ningsih, Surya (2014), Tahapan Model Pembelajaran Problem Based Learning) Dalam

Kurikulum 2013. https://www.kompasiana.com/2014/8/8/tahapan- model-

pembelajaran-problem-based-learning-dalam-kurikulum-2013, diakses 8 Agustus 2014

Rerung, Nensy., Sinon, L.S.I., \& Widyaningsih, W. Sri (2017). Penerapan Model Pembelajaran Problem Based Learning (PBL) Untuk Meningkatkan Hasil Belajar Peserta Didik SMA PadaMateri Usaha dan Energi. P-ISSN: 2303- 1832 Jurnal Ilmiah Pendidikan Fisika Al-BiRuNi, 06 (1) (2017) 47-55 e-ISSN: 2503-023X. P-ISSN: 23031832, bulan April 2017, from DOI : 10.24042/jpifalbiruni.v6i1.597

Shofiyah, Noly., \& Wulandari, E, Fitria (2018). Model Problem Based Learning (PBL) Dalam Melatih Scientific Reasoning . JPPIPA, Vol. 3 No. 12018 Jurnal Penelitian Pendidikan IPA http://journal.unesa.ac.id/index.php/jppipa, from DOI: http://dx.doi.org/10.26740/jppipa.v3n1.p33-38

Ulva, Varicha., Ibrohim \& Sutopo (2017). Mengembangkan Sikap Ilmiah Siswa SMP Melalui Pembelajaran Inkuiri Terbimbing Pada Materi Ekosistem. Jurnal Pendidikan: Teori, Penelitian, dan Pengembangan Volume: 2 Nomor: 5 Bulan Mei Tahun 2017, eISSN: 2502-471X DOAJ- SHERPA/RoMEO-Google ScholarIPIhttp://journal.um.ac.id/index.php/jptpp/ from DOI: http://dx.doi.org/10.17977/jptpp.v2i5.9077

Warsono \& Hariyanto. (2012). Pembelajaran Aktif : Teori dan Asesmen. Bandung : PT. Remaja Rosdakarya. 